\title{
Adoption of Self-Service Technologies Among Banking Customers: A Revisit
}

\author{
Irbha Magotra \\ Shri Mata Vaishno Devi University \\ Jyoti Sharma \\ Shri Mata Vaishno Devi University \\ Supran Kumar Sharma \\ Shri Mata Vaishno Devi University
}

The introduction of self-service technologies (SSTs) in the banking industry has been emerging as one of the significant business drivers that facilitate customers in operating their bank accounts. Considering this, the present study has made an attempt to pierce the existing literature with reference to the adoption of SSTs among banking customers. Particularly, the intent of the present article is to explore various personal (e.g., optimism, socioeconomic characteristics) and technology characteristics (e.g., perceived usefulness, perceived ease of use) that affect the acceptance of SSTs among the banking customers. Based on a review of the literature, a conceptual model for SST adoption has been proposed, thereby suggesting a roadmap for future research based on the gaps identified in the research concerning this area.

Keywords: self-service technology, banking industry, ATMs, Internet banking, mobile banking

\section{Introduction}

The introduction of self-service technologies (SSTs) in the banking sector has been emerging as one of the significant business drivers that facilitate customers in operating their bank accounts with more ease and effectiveness (Saxena, Sinha, \& Majra, 2016). Indeed, SSTs (e.g., ATMs, Internet banking, mobile banking) have allowed banking customers to carry out their banking transactions on 24/7 mode based on their requirements and convenience (Manikandan \& Chandramohan, 2016). The success of SSTs can be reflected by the augmented level of bank's profitability due to the introduction of the SSTs into the banking operations (Institute for Development and Research in Banking Technology, 2011). But despite the benefits provided by SSTs, its growth has been reported to be low as compared to the projected growth levels specifically with reference to developing nations like India (Kanal, 2014). In this context, a lack of wide acceptance of SSTs among the customers has been diagnosed as one of the primary concerns (Pillai \& Sreedhar, 2014).

Considering this, many attempts have been initiated to analyze the SST-adoption behaviors of the banking customers (Akinci, Aksoy, \& Atilgan, 2004; Sathye, 1999; Walczuch, Lemmink, \& Streukens, 2007; Yu, 2012). Because SSTs resemble information-technology innovation in different fields (e.g., online technologies, automated technologies), various attempts like the technology acceptance model (TAM; Davis, Bagozzi, \& Warshaw, 1989), unified theory of acceptance and use of technology (UTAUT; Venkatesh, Morris, Davis, \& Davis, 2003), innovation diffusion theory (IDT; Rogers, 1995), theory of reasoned action (TRA; Fishbein \& Ajzen, 1975), and theory of planned 
behavior (TPB; Ajzen, 1991) have been used by the researchers for exploring SSTs adoption phenomenon among the banking customers (e.g., Akturan \& Tezcan, 2012; Ariff, Min, Zakaun, \& Ishak, 2012; Giovanis, Binioris, \& Polychronopoulos, 2012; Pikkarainen, Pikkarainen Karjaluoto, \& Pahnila, 2004). Not only this, the technology readiness index (TRI) framework of Parasuraman (2000), which highlighted four personal traits of customers (optimism, innovativeness, discomfort, insecurity) in context of online and other automated technology, has also been replicated with reference to the adoption of SSTs among the customers (e.g., Berndt, Saunders, \& Petzer, 2010; Shambare, 2013; Walczuch et al., 2007). All the aforesaid replications have validated the relevance of the TRI traits in exploring the personal disposition of the customers toward the readiness of adopting SSTs.

Broadly, all the attempts of such kind have highlighted that the decision of the customers regarding technology adoption depends on three aspects, that is, technology attributes, presence of supporting conditions, and the personal attributes of the customers (Venkatesh et al., 2003). Technology attributes refers to the features of the technology, including perceived usefulness of the technology (Davis et al., 1989) and relative advantage (Rogers, 2003), whereas facilitating conditions refer to the presence of conditions (such as technical support, manual support, and so on) that support the application of SSTs for serving banking requirements of the customers (Venkatesh et al., 2003). Further, personal attributes refer to the customer-specific attributes-such as their technology readiness (Parasurman, 2000) and self-efficacy (Venkatesh, Thong, \& Xu, 2012) - that encourage or discourage customers from adopting the technology.

Considering these three aspects, numerous attempts have been made by the researchers in different settings to examine SSTs adoption behavior of the customers. For instance, Martins, Tiago, and Popovic (2014) attempted to explore the adoption of Internet banking based on UTAUT model developed by Venkatesh et al. (2003), whereas Cheng, Lam, and Yeung (2006) attempted to explore Internet banking adoption with TAM (developed by Davis et al., 1989). Further, literature has also been found to be enriched with studies integrating two or more models of such kind. For example, Podder (2005) explored Internet banking adoption dynamics through the integration of TAM with another model, perceived characteristics of innovation, developed by Moore and Benbasat (1991). But an insight into the studies of such kind has raised certain issues. Firstly, the studies of such kind indicate that while deciding the framework for the study, researchers have chosen a favored model (based on their perception or referral research) and have largely ignored the contributions of other alternative models in explaining SSTs adoption behavior of the customers (Venkatesh et al., 2003). Also, it has been found that certain constructs used by the researchers for exploring the SST adoption decision of the customers have been developed in contexts other than SSTs offered to the banking customers. For instance, perceived usefulness has been developed in TAM (Davis et al., 1989) with reference to employees using information technology at their workplace. Although perceived usefulness has been developed in context other than SSTs, the construct has been widely used with reference to the adoption of SSTs among the banking customers (Murali \& Mallikarjuna, 2014). Also, it has been found that the same construct has shown distinct impact on the SSTs adoption behavior of the customers in different contexts and settings. Similarly, self-efficacy has been found to show distinct (direct and indirect) impact on the SSTs adoption decision of the customers in different contexts (Nasri \& Charfeddine, 2012; Sundaravej, 2009). The analysis of all the studies of such kind have pointed toward the need to review all the aforementioned constructs before considering them for further research in the field of SSTs. Thus, with a view to analyze all such kind of constructs with reference to SSTs adoption among the banking customers, the present composition has been framed. 


\section{Framework of the Study}

Customers are the end users of the SSTs owing to which their behavior toward SSTs have been considered as one of the utmost vital aspects. Thus, scope of the present study has been confined only up to the subjective factors affecting the SSTs adoption behavior of the customers as these factors have been found to be influenced by the perception of the customers resulting from their value and belief system (Ratchford \& Barnhart, 2011). Accordingly, the present composition has focused only on customer-specific attributes and technology-specific attributes. Facilitating conditions have not been considered under the preview of the present study. Facilitating conditions refer to the objective factors present in the environment within which the SSTs have to be operated and have not been found to be affected by the perceptual differences of the customers (Venkatesh et al., 2003). Also, other factors including macroenvironment factors (e.g., legal factors, government policies) have not been reviewed in the present article to keep the focus on the subjective factors only as these factors are also the objective factors not prominently affected by the perception of the customers (Venkatesh et al., 2003). Besides, a decision to consider all the SSTs comprehensively (e.g., ATM, Internet banking) has been made instead of considering any particular SSTs with the assumption that the adoption of all these SSTs will be affected by the identical factors as all the SSTs facilitate direct customers-technology interaction (Meuter, Ostrom, Roundtree, \& Bitner, 2000).

Further, to examine the empirical as well as theoretical evidences from the literature with reference to technology adoption behavior of customers, the published research work available from research literature sources including JSTOR, Emerald, ScienceDirect and Springer have been assessed. Keeping the objective of the study in consideration, keywords such as SSTs, banks, technology adoption, TRI, TAM, UTAUT, IDT, TRA, TPB, ATM, Internet banking, and mobile banking were included to explore research work in this area since 1989 from the aforementioned sources of literature. Accordingly, 458 research articles have been retrieved and reviewed for accomplishing the objectives of the present study.

\section{Customer-Specific Antecedents of SSTs Adoption in Banks}

Basically, customer-specific attributes include two categories-personal traits of the customers (Parasuraman, 2000) and their socioeconomic characteristics (Venkatesh et al., 2003). Accordingly, various antecedents in both these categories have been examined in the present composition.

\section{Personal Traits of Customers}

Parasuraman (2000) has stated that the readiness of the customers toward technology adoption depends on their personal disposition toward technology adoption, which is one of the constituents of their personal traits. Accordingly, Parasuraman developed the TRI and highlighted four personal traits—optimism, innovativeness, discomfort, and insecurity. Optimism and innovativeness of the customers have been highlighted as technology enablers, whereas insecurity and discomfort have been identified as technology inhibitors. Developed in context of automated and other online technologies, a critical review of the four constructs has raised certain concerns. First, all the measures developed for assessing all the four personal traits have been found to be technology specific or user specific. For instance, the measure "You like the idea of doing business via computers because you are not limited to regular business hours" assessing optimism (Parasuraman, 2000, p. 312) will be applicable only in the contexts where the technology into consideration is computer or any other technology identical to information technology. Also, the measure "It is embarrassing when you have trouble with a high-tech gadget while people are watching" (p. 312) assessing discomfort will be applicable where use of the technology will be seen by others and not in contexts 
like mobile banking, wherein technology usage may or may not be seen by others. Likewise, the measure "Technology makes you more efficient in your occupation" (p. 312) assessing optimism was found to be applicable in context to the working individuals, thereby making this measure inappropriate in case of customers which belong to unemployed population. Because these measures are either technology specific or focused on an employed section of individuals, they need modifications to enhance their applicability with reference to SSTs implemented by the banks.

Despite this, a review of the literature has revealed that these four personal traits have been robustly used by the researchers for analyzing the technology adoption behavior of the users with reference to different technologies including SSTs offered by the banks either by dropping the statements from the original construct as developed by Parasuraman (2000) or by modifying the words used in the original measures (e.g., A. M. Chang \& Kannan, 2006; Elliott, Meng, \& Hall, 2009). For instance, Rose and Fogarty (2010) have considered few selected measures of all the four TRI constructs in their attempts to explore the technology readiness of the customers toward SSTs in Australia (like optimism has been assessed through three measures instead of 10 developed by Parasuraman, 2000). Likewise, Berndt et al. (2010) have considered the item "You like the idea of doing business via computers because you are not limited to regular business hours" (Parasuraman, 2000; p. 312). They have used the constructs by replacing "You" with "I" while exploring the adoption of banking technologies in developing nations like Africa despite the fact that TRI constructs were developed in context of information technology and the study by Berndt et al. (2010) was focused on banking technologies such as ATMs.

Also, the other two TRI constructs, discomfort and insecurity (Parasuraman, 2000), have been found to include some concerns other than those discussed earlier (e.g., technology specificity). For instance, insecurity has been defined as the distrust and skepticism of the banking customers in the performance of the SSTs for meeting their banking requirements and discomfort as the apprehension of loss of control over technology in TRI. Although discomfort and insecurity have been distinctly conceptualized in TRI, the items framed by Parasuraman (2000) for measuring these two constructs have been found to share some common characteristics-for instance, "Many new technologies have health or safety risks that are not discovered until people have used them" (p. 312) measuring discomfort and "You do not consider it safe to do any kind of financial business online" (p. 312) measuring insecurity. Both these measures include safety concern involved in adopting new technologies. Adding more, the items framed to assess discomfort were found to include environmental factors that are not customer specific like "Technical support lines are not helpful because they do not explain things in terms you understand" (p. 312) and "There is no such thing as manual for a high-tech product or service that's written in plain language" (p. 312). This also indicates the need to analyze these constructs before utilizing them for analyzing technology adoption behavior of the customers.

Further scrutinizing the TRI constructs, Ratchford and Barnhart (2011) developed another index, the technology adoption propensity (TAP) index, highlighting four personal traits: optimism, proficiency, dependability, and vulnerability. Optimism, according to Ratchford and Barnhart, has been specified as an individual characteristic, whereas efficiency as a technology characteristic. Hence, in the TAP index, efficiency has been dropped from the optimism construct, thereby keeping the scope of optimism limited to control and flexibility. These researchers have also stated that the new and improved technologies are more complex to use (Wood \& Moreau, 2006) and, as a result, enhance the frustration level of the customers (Strebel, O'Donnell, \& Myers, 2004). In such scenario, it is not the innovativeness but proficiency of the customers which stimulates them to adopt the technology (Ratchford \& Barnhart, 2011). Hence, proficiency, instead of innovativeness, has been included in the TAP index. In context of TAP index, proficiency has been conceptualized as "One's 
ability to quickly and easily learn to use new technologies as well as sense of being technologically competent" (p. 4).The meaning of proficiency has been found to include ability of the customers to operate technology on their own. But the development of measures assessing proficiency in case of TAP has been found to reflect innovativeness as defined by Parasuraman (2000). For instance, the measure "Other people come to me for advice on new technologies" (Ratchford \& Barnhart, 2011, p. 4) depicting proficiency represents a mirror image of the item "Other people come to you for advice on new technologies" (Parasuraman, 2000; p. 312) describing innovativeness. Although the TAP index has claimed to overcome shortcomings of TRI, the extensive review of literature has explored that the TAP index has not been widely validated specifically with reference to banking technologies.

Another stream of research has highlighted perceived risk as noteworthy forerunner of technology adoption decision of the customers. Perceived risk has been defined as the perception of the customers regarding the degree of uncertainty and unfavorable consequences attached with the performance of the technology (Bauer, 1960). Being a vital catalyst in online transactions (Ndubisi \& Sinti, 2006), perceived risk has also been found to exhibit significant impact on the decision of the customers to adopt SSTs (Kesharwani \& Bisht, 2012; Rotchanakitumnuai \& Speece, 2003). Further, the existing research work on technology adoption has also unveiled trust and privacy as significant predictors of the technology adoption decision of the customers in banks (Koo, Wati, \& Chung, 2013). Although different researchers have considered insecurity, discomfort, perceived risk, trust, vulnerability and privacy as significant predictors of adoption of banking technology for different categories of banking customers (e.g., Akturan \& Tezcan, 2012; Gupta \& Xu, 2010; Laukkanen, Sinkkonen, \& Laukkanen, 2008; Sentosa, Ming, Soebyakto, \& Mat, 2012; Yousafzai, Foxall, \& Pallister, 2010), yet all these have been identified to measure same characteristic of customers, that is, their perception regarding risk involved in using SSTs (Natarajan, Balasubramanian, \& Manickavasagam, 2010).

Besides risk, customers have also been found to choose SSTs if they have belief in their ability to operate SSTs on their own. Such competence, conceptualized as self-efficacy, has been found to cause significant impact on the formation of intentions of the individuals toward the usage of SSTs (Lichtenstein \& Williamson, 2006). Basically, the concept of self-efficacy has been taken from social cognitive theory, which has been defined as the belief of the individuals in their capabilities to handle a particular situation. With similar notion, self-efficacy has also shown significant impact on the technology adoption behavior of the customers (Bandura, 1986). Although explained through social cognitive theory, self-efficacy has been found to exhibit significant role in the technology adoption decision of the customers in different contexts and settings, such as computer use (Compeau \& Higgins, 1995), web-based educational software (Sundaravej, 2009), Facebook (Nasri \& Charfeddine, 2012), and so forth. The underlying rationale for the relationship between self-efficacy and technology adoption decision of the customers is that if the customers believe that they are competent enough to use technology on their own, they are more likely to use the technology. With the same rationale, self-efficacy has also been explored as significant determinant of the SSTs adoption decision of the customers (Johnson \& Marakas, 2000; Murphy et al., 1989).

It has been found that the customers with high self-efficacy are usually hard workers because they tend to learn and try new and improved technologies on their own (Ariff et al., 2012). Conversely, studies such as Venkatesh and Davis (2000); Puschel, Mazzon, and Hernandez (2010); and Brown, Zaheeda, Douglas, and Stroebel (2003) have highlighted that self-efficacy does not exhibit significant direct impact on the technology adoption decision of the customers. Instead, such studies have explored significant indirect impact of self-efficacy on technology adoption decision of the customers (Venkatesh et al., 2012) with the underlying reason that the confidence of the customers in their 
ability to operate the technology (i.e., their self-efficacy) make the use of technology easier for such customers due to which they tend to adopt the technology.

Further, the literature has also recognized the role of the social circle of customers in their decision of adopting the technology. Conceptualized as social influence, it has been defined as the degree to which customers are influenced by the opinion of individuals in their social circle regarding technology adoption (Venkatesh et al., 2003). In this regard, the scope of social influence includes family, friends, and colleagues of the customers. It also includes the group to which they belong and the group which they want to join (Ajzen, 1991; Davis et al., 1989, Taylor \& Todd, 1995). Although originally explained through the UTAUT model (Venkatesh et al., 2003), social influence has also been found to exhibit significant impact on the SSTs adoption decision of the customers (Baraghani, 2008), with the explanation that customers, who are highly influenced by their social circle, tend to adopt SSTs if the persons in their social circle are either using SSTs or recommend them to use the SSTs offered by the banks. Further, other streams of research-that is, TRA (developed by Fishbein \& Ajzen, 1975) and TPB (developed by Ajzen, 1991) — have also highlighted subjective norms as important predictor of the technology adoption decision of the banking customers (Ajzen, 1991; Davis et al., 1989, Taylor \& Todd, 1995). It has also been found to exhibit significant impact on the SSTs adoption decision of the customers (Al-Majali, 2011). However, social influence and subjective norms have been found to share some common features, that is, the perception of people important to customers. In fact, social influence has wider scope than subjective norms. Subjective norms have also been found to include acceptance of the technology by the people important to the customers (Ajzen, 1991; Davis et al., 1989), whereas social influence has been found to encompass the acceptance of the technology by the reference group to which the customers want to associate (Thompson, Higgins, \& Howell, 1991). Further, social influence has also been found to include impact of technology adoption on the social status of the customers (Moore \& Benbasat, 1991).

Besides, studies such as Lu, Yu, andLiu (2009); Yu (2012), and Venkatesh and Davis (2000) have stated that the social factors (social influence or subjective norms) do not directly impact the decision of the customers instead these factors will induce the customers to perceive technology usefulness in serving their needs owing to which they may adopt such technologies. However, the study by $\mathrm{Al}$ Qeisi (2009) found that the social factors do not play significant role in the technology adoption decision of the customers.

Further, the literature has also highlighted significant impact of various other factors, such as habit and perceived behavioral control, developed in different technology adoption models, such as UTAUT and UTAUT2 on the technology adoption decision of the customers either directly or indirectly. Among such, the factors like perceived behavioral control has been criticized based on its conceptual framework and modification has been recommended and considered (Venkatesh et al., 2003). Perceived behavioral control has been referred as the perceived ease or difficulty involved in performing behavior (Ajzen, 1991) and it has been found to be inclusive of two factors-self-efficacy and facilitating conditions. As discussed earlier also, self-efficacy is a customer-specific attribute, whereas, facilitating conditions are the factors prevailing in environment (e.g., technical support, manual support) that ease the operation of the technology. On account of this, researchers, like Venkatesh et al. (2003) have discarded the use of perceived behavioral control instead they have considered facilitating conditions separately in the UTAUT model and explored significant impact of it on the technology adoption decision of the customers.

Similarly, habit has also been identified as one of the significant predictors of technology adoption decision of customers in the UTAUT2 model (Murray \& Haubl, 2007; Venkatesh et al., 2012). It has been defined as the tendency to use technology out of learning (Limayem, Hirt, \& Chin, 2001). Habit 
makes the use of technology obvious to the customers, and as a result, such customers tend to use new and improved technologies (Beregeron et al, 1995; Thompson et al., 1991). Being a vital catalyst in case of technologies like mobile Internet technology (Venkatesh et al., 2012) and online shopping (Chiu, Hsu, Lai, \& Chang, 2012), habit may unveil significant impact in case of SSTs also but not considerable studies have been made in the past depicting role of habit in the adoption of SSTs. Like habit, another significant predictor of technology adoption that has not been explored extensively with respect to banking technologies is psychological resilience. Psychological resilience has been conceptualized as the tendency of the customers to bounce back from any kind of rejection or failure. Such tendency found to have significant impact on the decision of the customers to adopt technology (Bakker, Gieveld, \& Van, 2006). Psychologically resilient people tend to try new and improved technologies owing to their strong belief system and achievement orientation even if they have faced earlier any kind of technology failure (Luthans \& Youssef, 2007; Verhoef et al., 2009). Carrying the same notion to SSTs offered by banks, it can be inferred that psychological resilience may play significant role in the decision of the banking customers with respect to the adoption of SSTs that requires empirical validation.

\section{Socioeconomic Indicators of SSTs Adoption}

The studies in the field of technology adoption of banking customers have also highlighted significant impact of socioeconomic characteristics of customers on their technology adoption decision.

Socioeconomic indicators have been examined as both direct as well as indirect antecedents of technology adoption (J. Chang \& Samuel, 2004; Elliott et al., 2009; Lee, Cho, Xu, \& Fairhurst, 2010; Nilsson, 2007), and the results have been found to vary across different contexts and studies. For instance, Nilsson (2007) identified that male customers who are young, well-educated, and in a high income group are more likely to adopt banking technologies in Estonia, whereas in Sweden, no significant difference on the technology adoption decision of the customers has been explored on the basis of their age, gender, and income level. Further, Laforet and Li (2005) identified a significant impact of gender on technology adoption decision of the banking customers in China, whereas age and education have been found to cause insignificant impact on the technology adoption decision of the customers.

Besides, the research has also highlighted significant indirect impact of socioeconomic characteristics on the technology adoption decision of the customers through technology attributes, that is, perceived usefulness and perceived ease of use (e.g., AbuSanab \& Pearson, 2007; Vatnani \& Verma, 2014) and through personal characteristics of customers, such as optimism and innovativeness (e.g., Kim, Malhotra, \& Narasimhan, 2005; Lee et al., 2010; Mansor \& Chemat, 2009). Furthermore, Yousafzai and Yani-de-Soriano (2012) stated that socioeconomic characteristics influence behavioral intentions of the customers toward SSTs adoption, and such intentions cause significant direct impact on the decision of the customers to adopt SSTs.

\section{Technology-Specific Antecedents of SSTs Adoption in Banks}

Not only customer-specific but technology-specific attributes may also effect the decision of the customers to adopt technology. With this view, different streams of studies have focused particularly on technology-specific attributes. In this regard, Davis et al. (1989) developed the TAM, wherein two technology-specific attributes-perceived usefulness and perceived ease of use-have been explored as the significant determinants of the technology adoption decision of the customers with reference to information technology. Considering TAM, various researchers have attempted to explore impact of perceived usefulness on the technology adoption decision of the customers with reference to different technologies including SSTs offered by the banks (Abdel-Wahab, 2008; Akturan \& Tezcan, 
2012; Ariff et al., 2012; Cheng et al., 2006). Perceived usefulness has been denoted as the degree to which customers believe that using the technology would enhance their performance (Davis, 1993). With reference to SSTs offered by banks, the scope of perceived usefulness include wide assortment of activities performed by SSTs, for instance, money transfers, draft requests, bill payments, TDS, and so on (Kesharwani \& Bisht, 2012). The more activities can be performed by using SSTs, the more likely the customers are to adopt such technologies (Pikkarainen et al., 2004).

Another stream of research, that is, the IDT developed by Rogers (2003), has highlighted relative advantage as significant predictor of the SSTs adoption decision of the customers (Al-Jabri \& Sohail, 2012; Moore \& Benbasat, 1991). Furthermore, Venkatesh et al. (2003), through the development of UTAUT model, unveiled performance expectancy as significant predecessor of technology adoption decision of the customers. Although different streams of research have identified perceived usefulness, relative advantage and performance expectancy as vital antecedents of the SSTs adoption decision of the customers, yet studies have highlighted resemblance of these three aforementioned constructs (e.g., AbuSanab \& Pearson, 2007; Martins et al., 2014; Moore \& Benbasat, 1991; Venkatesh et al., 2003; Zhou, Lu, \& Wang, 2010) and, therefore, recommended use of any of these three constructs. However, an insight into the development and conceptualization of these three constructs have revealed that these three constructs are different from each other both conceptually as well as according to the measures developed for assessing them.

Relative advantage, as originally proposed by Rogers (2003) in the IDT, has been referred as the benefits derived from using the technology and includes enhanced efficiency, economic benefits and enhanced status, whereas Parasuraman (2000) has stated that efficiency is a customer-specific characteristic and is a part of belief of the customers regarding the performance of the technology. Likewise, performance expectancy has also indicated customer-specific characteristic, that is, expectations of the customers regarding the performance of technology believed to be affected by their belief system. Moreover, all the three constructs, namely, perceived usefulness, relative advantage, and performance expectancy, have been developed in mandatory settings, thereby limiting the use of all the measures designed to assess these three aforesaid constructs in context of voluntary settings including SSTs (AbuSanab \& Pearson, 2007; Yu, 2012). For instance, measures of perceived usefulness as framed by Davis et al. (1989) stated that using the technology improves the job performance of the employee which cannot be applied in context of SSTs offered by the banks.

Besides, researchers, in past, have also experienced insignificant impact of perceived usefulness and other related technology attributes, namely, relative advantage and performance expectancy on the technology adoption decision of the customers. For instance, Aboelmaged and Gebba (2013) uncovered insignificant impact of perceived usefulness on the technology adoption decision of the customers with the rationale that belief in the effectiveness of the SSTs will only frame positive feeling toward technology and do not develop positive intentions toward the adoption of the technology. Likewise, Yu (2012) also highlighted that performance expectancy exhibit significant indirect impact on the technology adoption decision of the customers with the reason that the customers are well acquaint with the benefits of new and improved technologies owing to which they are not concerned about the performance expectancy of the technology. Besides, these three constructs and more specifically, perceived usefulness has been found to be more robustly used in context of SSTs offered by banks in different countries and cultures (e.g., Dasgupta, Paul, \& Fuloria, 2011; Luarn \& Lin 2005; Sripalawat, Thongmak, \& Ngramyarn, 2011).

Like perceived usefulness, perceived ease of use has also been found to have significant impact on the technology adoption decision of the customers with reference to different technologies including SSTs (e.g., Aboelmaged \& Gebba, 2013; Cheng et al., 2006). It has been conceptualized as the extent 
to which the use of the system would enhance the job performance of the employees at their workplace (Davis et al., 1989). Although perceived ease of use has been developed in mandatory settings in TAM along with perceived usefulness (Davis et al., 1989), yet it has also been validated in voluntary setting context including SSTs (Al-Jabri \& Sohail, 2012; Wang, Wang, Lin, \& Tang, 2003; $\mathrm{Yu}, 2012)$. But, the relationship between perceived ease of use and the decision to adopt technology have publicized different results in different research settings. Some studies have identified significant direct impact of perceived ease of use on the intentions to use SSTs (Safeena, Hundewale, \& Kamani, 2011). Conversely, wide array of studies have shown significant indirect impact of perceived ease of use on the adoption of SSTs through perceived usefulness in different contexts and settings (e.g., Kesharwani \& Bisht, 2012; Maditinos, Chatzoudes, \& Sarigiannidis, 2013), with the underlying reason being that the ease with which technologies can be operated make the technology more effective, which will further induce customers to adopt the technology. Moreover, the research reservoir has also included complexity (developed in IDT by Rogers, 2003) and effort expectancy (developed in UTAUT by Venkatesh et al., 2003) as significant determinants of the decision to adopt technology. But these constructs have been viewed as mirror image of perceived ease of use both conceptually as well as according to the measures developed for assessing these three constructs in the respective models (Venkatesh et al., 2003).

On similar lines, the extensions of the models, such as, TAM2 (Venkatesh \& Davis, 2000) and UTAUT2 (Venkatesh et al., 2012) have also uncovered various direct as well as indirect antecedents of technology adoption decision of the customers including image, output quality, and so on, but the literature has been found to be fallen short in exploring such factors with reference to SSTs offered by the banks for which the recent entry of these models in the technology adoption literature can be one of the plausible reasons. Adding more, various factors in different models, like job relevance developed in TAM2 have been found to be of less relevance in context to the SSTs offered by the banks. Job relevance has been defined as the degree to which the use of the system is applicable to the job of employee(s), which cannot be applied in case of voluntary settings like the case of SSTs adoption among the customers. Thus, there is a need to critically analyze such factors before selecting them as probable antecedents to assess SSTs adoption behavior of the banking customers.

\section{Roadmap Ahead for Research}

The review of the literature pertaining to the subjective antecedents of SSTs adoption has unveiled array of factors (in both the categories, i.e., customer-specific and technology-specific antecedents) that may affect the decision of the customers toward the adoption of SSTs offered by the banks. But, an analytical insight into different studies has raised certain issues, thereby laying the foundation to carry more research in the future. Primarily, it has been found that different streams of research have unveiled a significant impact of various personal traits of the customers on their technology readiness with reference to SSTs offered by the banks. However, the existing literature has fallen short in providing studies focusing on a comprehensive array of personal traits while exploring technology readiness of the customers. Optimism, self-efficacy, habit, and so forth have not been explored comprehensively in a single study. For instance, the TRI developed by Parasuraman (2000) focused only on four personal traits, namely, optimism, innovativeness, discomfort, and insecurity and exclude other personal traits, such as self-efficacy and habit. Likewise, Compeau and Higgins (1995) focused only on some of the customer-specific attributes, like self-efficacy. Further, models including TRA (Ajzen, 1991; Fishbein \& Ajzen, 1975) focused on only subjective norm and perceived

behavioral control, respectively, while exploring technology adoption behavior of customers. Thus, an attempt of such kind should be made in future to analyze cumulative impact of such traits on the technology adoption level of the customers with reference to SSTs offered by the banks. While piercing the existing literature, it has also been found that maximum of the research with reference 
to SSTs adoption behavior of the customers is either focused on technology-specific attributes or customer-specific attributes. For instance, TRI focused on personal traits only while TAM developed by Davis et al. (1989) focused on technology-specific attributes only. Further, the UTAUT model developed by Venkatesh et al. (2003) considered technology specific attributes along with socioeconomic characteristics of the customers while exploring technology adoption behavior of the customers and failed to consider other customer-specific attributes. No substantial research efforts have been made to explore relationship between both customer-specific and technology-specific attributes even though both these categories of attributes have been found to be associated with each other (Brown et al., 2003; Walczuch et al., 2007). Thus, extensive attempts may be made in this regard so as to analyze whether there exist significant association between these two categories of attributes with reference to SSTs offered by the banks in different settings. Considering these aspects into contemplation, the present composition has proposed a theoretical model (as represented Figure 1) to study considering both customer-specific and technology-specific attributes together in a single study with the main aim of analyzing technology adoption behavior of the customers more comprehensively and in entirety.

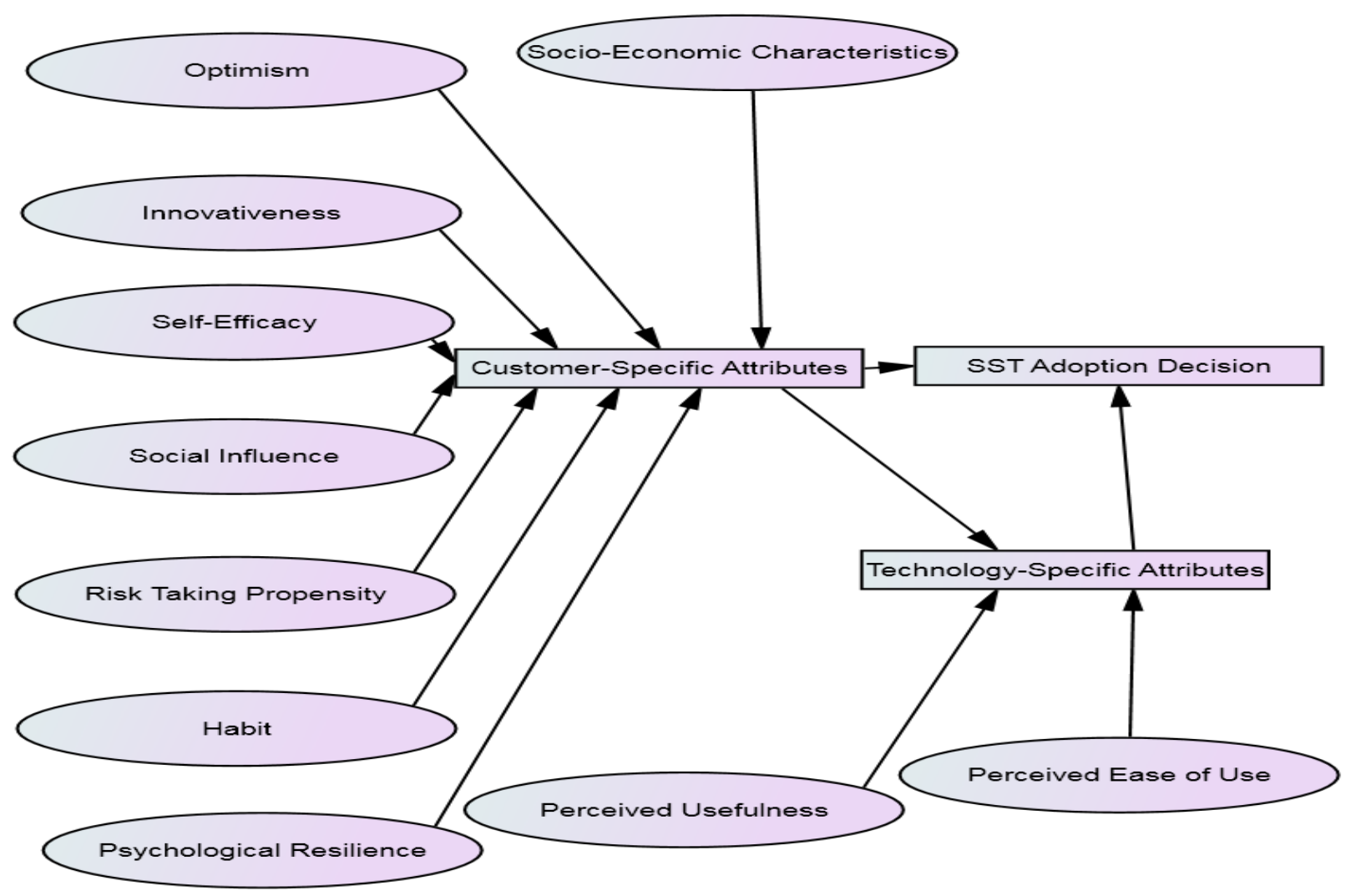

Figure1. Conceptual Model of Self-Service Technology (SST) Adoption Behavior of Banking Customers

The development of the conceptual model of SST adoption behavior of banking customers is based on the extensive review of literature in this context, as summarized in Table 1. 
Table 1. Literature Support for Constructs used in the Development of Conceptual Model Constructs

\begin{tabular}{|c|c|c|}
\hline Constructs & Relevant Studies & Major Findings \\
\hline \multicolumn{3}{|l|}{ Personal traits } \\
\hline Optimism & Parasuraman (2000); Ratchford and Barnhart & Optimism and innovativeness constitute personal \\
\hline Innovativeness & $\begin{array}{l}\text { (2011); Elliott et al. (2009); A. M. Chang and } \\
\text { Kannan (2006); Rose and Fogarty (2010); Wood } \\
\text { and Moreau (2006) }\end{array}$ & $\begin{array}{l}\text { disposition toward technology adoption and both } \\
\text { act as technology enablers, thereby insisting the } \\
\text { users to adopt the technology }\end{array}$ \\
\hline Self-efficacy & $\begin{array}{l}\text { Compeau and Higgins (1995); Lichtenstein and } \\
\text { Williamson (2006); Sundaravej (2009); Nasri and } \\
\text { Charfeddine (2012); Johnson and Marakas } \\
\text { (2000); Murphy et al. (1989); Ariff et al. (2012); } \\
\text { Venkatesh and Davis (2000); Venkatesh et al. } \\
\text { (2012) }\end{array}$ & $\begin{array}{l}\text { The belief of the customers in their ability to operate } \\
\text { the technology on their own has a positive impact } \\
\text { on their technology adoption decision }\end{array}$ \\
\hline Social influence & $\begin{array}{l}\text { Venkatesh et al. (2003); Ajzen (1991); Davis et al. } \\
\text { (1989); Taylor and Todd (1995); Baraghani } \\
\text { (2008); Fishbein and Ajzen (1975); Al-Majali } \\
\text { (2011); Thompson et al. (1991); Moore and } \\
\text { Benbasat (1991); Lu et al. (2009); Yu (2012); Al- } \\
\text { Qeisi (2009) }\end{array}$ & $\begin{array}{l}\text { The customers, who are highly influenced by their } \\
\text { social circle, tend to adopt the technology when } \\
\text { the persons in their social circle are either using } \\
\text { the technology or recommend it }\end{array}$ \\
\hline $\begin{array}{r}\text { Risk-taking } \\
\text { propensity }\end{array}$ & $\begin{array}{l}\text { Bauer (1960); Ndubisi and Sinti (2006); Kesharwani } \\
\text { and Bisht (2012); Rotchanakitumnuai and } \\
\text { Speece (2003); Natarajan et al. (2010); Gupta } \\
\text { and Xu (2010); Akturan and Tezca (2012); } \\
\text { Yousafzai et al. (2010); Laukkanen et al. (2008); } \\
\text { Laforet and Li (2005) }\end{array}$ & $\begin{array}{l}\text { The extent of uncertainty, discomfort, etc., involved } \\
\text { in operating the technology will adversely affect } \\
\text { the decision of the customers toward technology } \\
\text { adoption }\end{array}$ \\
\hline Habit & $\begin{array}{l}\text { Venkatesh et al. (2012); Murray and Haubl (2007); } \\
\text { Thompson et al. (1991); Beregeron et al. (1995); } \\
\text { Chiu et al. (2012); Bakker et al. (2006); Verhoef } \\
\text { et al. (2009); Luthans and Youssef (2007) }\end{array}$ & $\begin{array}{l}\text { Habit makes the use of technology obvious to } \\
\text { customers; as a result, they tend to use new and } \\
\text { improved technologies }\end{array}$ \\
\hline $\begin{array}{l}\text { Psychological } \\
\text { resilience }\end{array}$ & $\begin{array}{l}\text { Bakker et al. (2006); Verhoef et al. (2009); Luthans } \\
\text { and Youssef (2007) }\end{array}$ & $\begin{array}{l}\text { Customers, who do not carry the burden of past } \\
\text { technology performance into consideration, are } \\
\text { more likely to adopt new and improved } \\
\text { technologies }\end{array}$ \\
\hline
\end{tabular}

Tables continues technologies 


\begin{tabular}{|c|c|c|}
\hline Constructs & Studies Referred & Major Findings \\
\hline $\begin{array}{l}\text { Socioeconomic } \\
\text { characteristics }\end{array}$ & $\begin{array}{l}\text { Nilsson (2007); J. Chang and Samuel (2004); Elliott } \\
\text { et al. (2009); Lee et al. (2010); Laforet and Li } \\
\text { (2005); AbuSanab and Pearson (2007); Vatnani } \\
\text { and Verma (2014); Kim et al. (2005); Mansor and } \\
\text { Chemat (2009); Yousafzai and Yani-de-Soriano } \\
\text { (2012) }\end{array}$ & $\begin{array}{l}\text { Characteristics such as age, income, and } \\
\text { qualifications also affect the technology adoption } \\
\text { decision of the customers }\end{array}$ \\
\hline \multicolumn{3}{|l|}{ Technology attributes } \\
\hline Perceived usefulness & $\begin{array}{l}\text { Ariff et al. (2012); Akturan and Tezcan (2012); } \\
\text { Abdel-Wahab (2008); Cheng et al. (2006); } \\
\text { Kesharwani and Bisht (2012); Pikkarainen et al. } \\
\text { (2004); Venkatesh et al. (2003); Martins et al. } \\
\text { (2014); AbuSanab and Pearson (2007); Moore } \\
\text { and Benbasat (1991); Zhou et al. (2010) }\end{array}$ & $\begin{array}{l}\text { Customers who believe that the new and improved } \\
\text { technology is more effective than the traditional } \\
\text { technology in carrying out the activity for which it } \\
\text { has been introduced tend to adopt the new } \\
\text { technology }\end{array}$ \\
\hline Perceived ease of use & $\begin{array}{l}\text { Aboelmaged and Gebba (2013); Cheng et al. (2006); } \\
\text { Davis et al. (1989); Wang et al. (2003); Yu (2012); } \\
\text { Al-Jabri and Sohail (2012); Safeena et al. (2011); } \\
\text { Kesharwani and Bisht (2012); Maditinos et al. } \\
\text { (2013) }\end{array}$ & $\begin{array}{l}\text { Customers with the belief that the new and } \\
\text { improved technology is easy to use are more likely } \\
\text { to adopt it }\end{array}$ \\
\hline
\end{tabular}


The technology adoption phenomenon of the banking customers regarding SSTs has not yet (to the best of our knowledge) been studied comprehensively and entirely from different perspectives, especially in an Indian context. The aim of such attempt is to study technology adoption behavior of the customers from many angles in order to get a holistic review. This integration may be helpful in understanding the technology adoption dynamics of banking customers in a more parsimonious way considering the technology adoption phenomenon from many angles in a single study. Indeed, such analysis will constitute a keystone to continue with the study focusing on technology adoption dynamics from an applied perspective. The empirical validation of the aforesaid theoretical model will enable banks to more comprehensively explore the multidimensional technology adoption phenomenon more comprehensively in an Indian context because the factors mentioned in the present composition are found to have a significant impact on technology adoption decision of the customers in different settings, such as Malaysia, United States, Taiwan, Korea, United Arab Emirates, Tehran, Finland, and Iran.

Further, the testing of the aforementioned model should be done considering certain limitations of the model. First, the proposed model has focused only on the subjective factors of customer-specific and technology-specific attributes. The literature has also been found to include certain other factors affecting the technology adoption decision of the customers, such as facilitating conditions and macroenvironmental factors (e.g., legal and economic factors). Such factors may exhibit significant contribution in the SSTs adoption behavior of the customers and the same can also be included in the model and tested. Second, the proposed model in the present composition has taken all the SSTs comprehensively considering the fact that all different SSTs introduced by the banks focus on direct interaction between customers and banking services, which may or may not be the case until the same will get support of some empirical evidence.

Apart from it, extensive review of the literature has highlighted issues involved in the development and conceptualization of different measures. Therefore, it is suggested that critical evaluation of the constructs as well as the measures developed for assessing the constructs should be made before using the constructs for analyzing SSTs adoption behavior of the banking customers. Furthermore, some factors like habit and psychological resilience have not been examined exhaustively in context of SSTs. Hence, the impact of such factors combined with other factors (such as optimism and innovativeness) may further deepen the study of adoption of SSTs by the banking customers. All such kind of assessments may provide more decisive as well as comprehensive insight into the SSTs adoption phenomenon of the customers.

\section{References}

Abdel-Wahab, A. G. (2008). Modeling students' intention to adopt E-Learning: A case from Egypt. The Electronic Journal of Information Systems in Developing Countries, 34, 1-13.

Aboelmaged, G., \& Gebba, T. R. (2013). Mobile banking adoption: An examination of technology acceptance model and theory of planned behavior. International Journal of Business Research and Development, 2, 35-50.

AbuSanab, E., \& Pearson, J. M. (2007). Internet banking in Jordan: The unified theory of acceptance and use of technology (UTAUT) perspective. Journal of Systems and Information Technology, $9,78-107$.

Ajzen, I. (1991). The theory of planned behavior. Organizational Behavior and Human Decision Processes, 50, 179-211. doi:10.1016/0749-5978(91)90020-T 
Akinci, S., Aksoy, S., \& Atilgan, E. (2004). Adoption of internet banking among sophisticated consumer segments in an advanced developing country. International Journal of Bank Marketing, 22, 212-232.

Akturan, U., \& Tezcan, N. (2012). Mobile banking adoption of the youth market: Perceptions and intentions. Marketing Intelligence \& Planning, 30, 444-459

Al-Jabri, I. M., \& Sohail, M. S. (2012). Mobile banking adoption: Application of diffusion of innovation theory. Journal of Electronic Commerce Research, 13, 373-385.

Al-Majali, M. (2011). The use of theory reasoned of action to study information technology in Jordan. Journal of Internet Banking and Commerce, 16, 1-11.

Al-Qeisi, K. (2009). Analyzing the use of UTAUT model in explaining an online behavior: Internet banking adoption (Unpublished doctoral dissertation). Brunel University, London, United Kingdom.

Ariff, M. S. M., Min, Y. S., Zakaun, N., \& Ishak, N. (2012). The impact of computer self-efficacy and technology acceptance model on behavioral intention in internet banking system. Review of Integrative Business and Economics, 2, 587-601.

Bakker, A. B., Gieveld, J. H., \& Van R. K. (2006). A study on burnout, work engagement and performance. Diemen, The Netherlands: Right Management Consultants.

Bandura, A. (1986). Social foundations of thought and action: A social cognitive theory. Englewood Cliffs, NJ: Prentice Hall.

Baraghani, S. N. (2008). Factors influencing the adoption of Internet banking (Master's thesis). Luleå, Sweden: Luleå University of Technology.

Bauer, R. A. (1960). Consumer behavior as risk-taking, In R. S. Hancock (Ed.), Dynamic marketing for a changing world: Proceedings of the 43rd national conference of the American Marketing Association (pp. 389-398). Osaka, Japan: World Scholar.

Berndt, A. D., Saunders, S. G., \& Petzer, D. J. (2010). Readiness for banking technologies in developing countries. Southern African Business Review, 14, 47-76.

Brown, I., Zaheeda, C., Douglas, D., \& Stroebel, S., (2003). Cell phone banking: Predictors of adoption in South Africa: An exploratory study. International Journal of Information Management, 23, 381-394.

Chang, A. M., \& Kannan, P. K. (2006). Employee technology readiness and adoption of wireless technology and services. Presented at the 39th annual Hawaii International Conference on System Sciences, Kauia, HI.

Chang, J., \& Samuel, N. (2004). Internet shopper demographics and buying behavior in Australia. The Journal of American Academy of Business September, 5, 171-176.

Cheng, T. C. E., Lam, D. Y. C., \& Yeung, A. C. L. (2006). Adoption of internet banking: An empirical study in Hong Kong. Decision Support System, 42, 1558-1572.

Chiu, C. M., Hsu, M. H., Lai, H., \& Chang, C. M. (2012). Re-examining the influence of trust on online repeat purchase intention: The moderating role of habit and its antecedents. Decision Support System, 53, 835-845.

Compeau, D. R., \& Higgins, C. A. (1995). Application of social cognitive theory to training for computer skills. Information Systems Research, 6, 118-143.

Dasgupta, S., Paul, R., \& Fuloria, S. (2011). Factors affecting behavioral intentions toward mobile banking usage: Empirical evidence from India. Romanian Journal of Marketing, 3, 6-28. 
Davis, F. D. (1993). User acceptance of information technology: System characteristics, user perceptions and behavioral impacts. International Journal of Man-Machine Studies, 38, $475-487$.

Davis, F. D., Bagozzi, R. P., \& Warshaw, P. R. (1989). User acceptance of computer technology: A comparison of two theoretical models. Management Science, 35, 982-1002.

Elliott, K. M., Meng, J., \& Hall, M.C. (2009). Technology readiness and the likelihood to use selfservice technology: Chinese vs. American consumers. Marketing Management Journal, 18, $20-31$.

Fishbein, M., \& Ajzen, I. (1975). Belief, attitude, intention and behavior. Boston, MA: AddisonWesley.

Giovanis, A. N., Binioris, S., \& Polychronopoulos, G. (2012). An extension of TAM model with IDT and security/privacy risk in the adoption of internet banking services in Greece. EuroMed Journal of Business, 7, 24-53.

Gupta, S., \& Xu, H. (2010). Examining the relative influence of risk and control on intention to adopt risky technologies. Journal of Technology, Management and Information, 5, 22-37.

Institute for Development and Research in Banking Technology. (2011). Technology in banking: Insight and foresight. Retrieved from https://www.idrbt.ac.in/assets/publications/BT\%20Awards\%20Review/Technology\%20in\%20B anking\%20(2011).pdf

Johnson, R. D., \& Marakas, G. M. (2000). The role of behavioral modeling in computer skills acquisition: Toward refinement of the model. Information Systems Research, 11, 403-417.

Kanal, N. (2014). Growth of mobile banking in India below expectations: RBI. Retrieved from http://tech.firstpost.com/news-analysis/growth-of-mobile-banking-in-india-belowexpectations-rbi-207199.html

Kesharwani, A., \& Bisht, S. S. (2012). The impact of trust and perceived risk on internet banking adoption in India: An extension of technology acceptance model. International Journal of Bank Marketing, 30, 303-322.

Kim, S. S., Malhotra, N. K., \& Narasimhan, S. (2005). Two competing perspectives on automatic use: A theoretical and empirical comparison. Information Systems Research, 16, 418-432.

Koo, C., Wati, Y., \& Chung, N. (2013). A study of mobile and internet banking service: Applying for IS success model. Asia Pacific Journal of Information Systems, 23, 65-86.

Laforet, S., \& Li, X. (2005). Consumers' attitudes toward online and mobile banking in China. International Journal of Bank Marketing, 23, 362-380.

Laukkanen, P., Sinkkonen, S., \& Laukkanen, T. (2008). Consumer resistance to internet banking: Postponers, opponents and rejecters. International Journal of Bank Marketing, 26, 440-455.

Lee, H., Cho, H. J., Xu, W., \& Fairhurst, A. (2010). The influence of consumer traits and demographics on intention to use retail self-service checkouts. Marketing Intelligence \& Planning, 28, 46-58.

Lichtenstein, S., \& Williamson, K. (2006). Understanding consumer adoption of IPAD Banking: In interpretive study in the Australian banking context. Journal of Electronic Commerce Research, 7, 50-66. 
Limayem, M., Hirt, S. G., \& Chin, W. W. (2001). Intention does not always matter: The contingent role of habit on IT usage behavior. Presented at the 9th European Conference on Information Systems, Bled, Slovenia.

Lu, J., Yu, C. S., \& Liu, C. (2009). Mobile data service demographics in urban China. The Journal of Computer Information Systems, 50, 117-126.

Luarn, P., \& Lin, H. H. (2005). Toward an understanding of the behavioral intention to use mobile banking. Computers in Human Behavior, 21, 873-891.

Luthans, F., \& Youssef, C. M. (2007). Emerging positive organizational behavior. Journal of Management, 33, 321-349.

Maditinos, D., Chatzoudes, D., \& Sarigiannidis, L. (2013). An examination of the critical factors affecting consumer acceptance of online banking: A focus on the dimensions of risk. Journal of Systems and Information Technology, 15, 97-116.

Manikandan, M., \& Chandramohan, S. (2016). Self-service banking technologies-opportunities and challenges. International Journal of Innovative Knowledge Concepts, 2, 1-4.

Mansor, N., \& Chemat, A. (2009). Islamic credit card: Are demographic factors a good indicator? Asian Social Science, 5, 17-26.

Martins, C., Tiago, O., \& Popovic, A. (2014). Understanding the Internet banking adoption: A unified theory of acceptance and use of technology and perceived risk application. International Journal of Information Management, 34, 1-13.

Meuter, M., Ostrom, A., Roundtree, R., \& Bitner, M. (2000). Self-service technologies: Understanding customer satisfaction with technology-based service encounters. Journal of Marketing, 64, $50-64$.

Moore, G. C., \& Benbasat, I. (1991). Development of an instrument to measure the perceptions of adopting and information technology innovation. Information Systems Research, 2, 192-222.

Murali, S. R., \& Mallikarjuna, V. (2014). Consumer adoption of net banking in Tier-III cities of Andhra Pradesh: An empirical study. International Journal of Scientific Research, 3, 269 272.

Murphy, C. A., Coover, D., \& Owen, S. V. (1989). Development and validation of the computer selfefficacy scale. Educational and Psychological Measurement, 49, 893-899.

Murray, K. B., \& Haubl, G. (2007). Explaining cognitive lock in: The role of shill-based habits of use in consumer choice. Journal of Consumer Research, 31, 77-88.

Nasri, W., \& Charfeddine, L. (2012). An exploration of Facbook.com adoption in Tunisia using technology acceptance model (TAM) and theory of reasoned action (TRA). Interdisciplinary Journal of Contemporary Research in Business, 4, 948-968.

Natarajan, T., Balasubramanian, S. A., \& Manickavasagam, S. (2010). Customer's choice amongst self-service technology (SST) channels in retail banking: A study using analytical hierarchy process (AHP). Journal of Internet Banking and Commerce, 15, 1-16.

Ndubisi, N. O., \& Sinti, Q. (2006). Consumer attitudes, system's characteristics and internet banking adoption in Malaysia. Management Research News, 29, 16-27.

Nilsson, D. (2007). A cross-cultural comparison of self-service technology use. European Journal of Marketing, 41, 367-381.

Parasuraman, A. (2000). Technology Readiness Index (TRI): A multi-item scale to measure readiness to embrace new technologies. Journal of Service Research, 2, 307-320. 
Pikkarainen, T., Pikkarainen K., Karjaluoto, H., \& Pahnila S. (2004). Consumer acceptance of online banking: An extension of technology acceptance model. Internet Research, 14, 224-235.

Pillai, R. S., \& Sreedhar, R. R. (2014). Banking in India: Evolution in technology. Retrieved from http://www.infosys.com/finacle/solutions/thought-papers/Documents/banking-in-Indiaevolution-in-technology.pdf

Podder, B. (2005). Factors influencing the adoption and usage of internet banking: A New Zealand perspective (Master's thesis). Auckland University of Technology, Auckland, New Zealand.

Puschel, J., Mazzon, J. A., \& Hernandez, J. M. C. (2010). Mobile banking: Proposition of an integrated adoption intention framework. International Journal of Bank Marketing, 28, $389-409$.

Ratchford, M., \& Barnhart, M. (2011). Development and validation of the technology adoption propensity (TAP) index. Journal of Business Research, 65, 1209-1215.

Rogers, E. M. (1995). Diffusion of innovations (4th ed.). New York, NY: Free Press.

Rogers, E. M. (2003). Diffusion of innovations (5th ed.). New York, NY: Free Press.

Rose, J., \& Fogarty, G. (2010). Technology readiness and segmentation profile of mature consumers. Academy of World Business, Marketing \& Management Development, 4. Retrieved from http://www.academyofworldbusiness.com/conf2010.htm

Rotchanakitumnuai, S., \& Speece, M. (2003). Barriers to Internet banking adoption: A qualitative study among corporate customers in Thailand. International Journal of Bank Marketing, 21, 312-323.

Safeena, R., Hundewale, N., \& Kamani, A. (2011). Customer's adoption of mobile-commerce: A study on emerging economy. International Journal of e-Education, e-Business, e-Management and e-Learning, 1, 228-233.

Sathye, M. (1999). Adoption of Internet banking by Australian consumers: An empirical investigation. International Journal of Bank Marketing, 17, 324-334.

Saxena, R., Sinha, M., \& Majra, H. (2016). Banking in India: Role of self-service technologies. Thriving in New World Economy, 5, 186-189.

Sentosa, I., Ming, C. W., Soebyakto, B. B., \& Mat, N. K. H. (2012). Structural equation modeling of Internet banking usage in Malaysia. Journal of Arts, Science and Commerce, 2, 75-86.

Shambare, R. (2013). Technology readiness and EFTPoS usage in Zimbabwe. International Journal of Business and Economic Development, 1, 13-22.

Sripalawat, J., Thongmak, M., \& Ngramyarn, A. (2011). M-banking in metropolitan Bangkok and a comparison with other countries. The Journal of Computer Information Systems, 51, 67-76.

Strebel, J., O'Donnell, K., \& Myers, J. G. (2004). Exploring the connection between frustration and consumer choice behavior in a dynamic decision environment. Psychology \& Marketing, 21, 1059-1076.

Sundaravej, T. (2009). Empirical validation of unified theory of acceptance and use of technology model (Dissertation). College of Business Administration, University of Missouri at Saint Louis.

Taylor, S., \& Todd, P. (1995). Understanding information technology usage: A test of competing models. Information Systems Research, 6, 144-176. 
Thompson, R. L., Higgins, C., \& Howell, J. M. (1991). Personal computing: Toward a conceptual model of utilization. MIS Quarterly, 15, 125-143.

Vatnani, R., \& Verma, S. (2014). Comprehensive framework for internet banking adoption: An empirical analysis in the India context. International Journal of Business Information System, 15, 307-324.

Venkatesh, V., \& Davis, F. D. (2000). A theoretical extension of the technology acceptance model: Four longitudinal field studies. Management Science, 46, 186-204.

Venkatesh, V., Morris, M. G., Davis, G. B., \& Davis, FD. (2003). User acceptance of information technology: Toward a unified view. MIS Quarterly, 27, 425-478.

Venkatesh, V., Thong, J. Y. L., \& Xu, X. (2012). Consumer acceptance and use of information technology: Extending the Unified theory of acceptance and use of technology. MIS Quarterly, 31, 157-178.

Verhoef, P. C., Lemon, K. N., Parasuraman, A., Roggeveen, A., Tsiros, M., \& Schlesinger, L.A. (2009). Customer experience creation: Determinants, dynamics and management strategies. Journal of Retailing, 85, 31-41.

Walczuch, R., Lemmink, J., \& Streukens, S. (2007). The effect of service employees' technology readiness on technology acceptance. Information \& Management, 44, 206-215.

Wang, Y. S., Wang, Y. M., Lin, H. H., \& Tang, T. I. (2003). Determinants of user acceptance of internet banking: An empirical study. International Journal of Service Industry Management, 14, 501-519.

Wang, Y. S., \& Shih, Y. W. (2009). Why do people use information kiosks? A validation of the unified theory of acceptance and use of technology. Government Information Quarterly, 26, 158-165.

Wood, S. L., \& Moreau, C. P. (2006). From fear to loathing? How emotion influences the evaluation and early use of innovations. Journal of Marketing, 70, 44-57.

Yousafzai, S., \& Yani-de-Soriano, M. (2012). Understanding customer-specific factors underpinning internet banking adoption. International Journal of Bank Marketing, 30, 60-81.

Yousafzai, S., Foxall, G. R., \& Pallister, J. G. (2010). Explaining internet banking behavior: Theory of reasoned action, theory of planned behavior or technology acceptance model? Journal of Applied Social Psychology, 40, 1172-1202.

Yu, C. (2012). Factors affecting individuals to adopt mobile banking: Empirical evidence from the UTAUT Model. Journal of Electronic Commerce Research, 13, 104-121.

Zhou, T., Lu, Y., \& Wang, B. (2012). Integrating TTF and UTAUT to explain mobile banking user adoption. Computers in Human Behavior, 26, 760-767.

The International Journal of Applied Management and Technology (IJAMT), sponsored by Walden University's School of Management, is a peer-reviewed, online journal that addresses contemporary national and international issues related to management and technology. The objectives of the IJAMT are to: (a) encourage collaborative and multi-disciplinary examinations of important issues in business and technology management, and (B) engage scholars and scholar-practitioners in a dynamic and important dialogue.

Walden University Publishing: http://www.publishing.waldenu.edu 